\title{
Molecular basis for the involvement of thymidine phosphorylase in cancer invasion
}

\author{
TAKENARI GOTANDA ${ }^{1,2}$, MISAKO HARAGUCHI ${ }^{2}$, TOKUSHI TACHIWADA ${ }^{1,2}$, REIKO SHINKURA $^{3}$, \\ CHIHAYA KORIYAMA ${ }^{3}$, SUMINORI AKIBA ${ }^{3}$, MOTOSHI KAWAHARA ${ }^{1}$, KENRYU NISHIYAMA ${ }^{1}$, \\ TOMOYUKI SUMIZAWA ${ }^{2}$, TATSUHIKO FURUKAWA ${ }^{2}$, HIROMITSU MIMATA $^{4}$, \\ YOSHIO NOMURA ${ }^{4}$, SHIN-ICHI AKIYAMA ${ }^{2}$ and MASAYUKI NAKAGAWA ${ }^{1}$
}

\begin{abstract}
Departments of ${ }^{1}$ Urology, ${ }^{2}$ Molecular Oncology, Field of Oncology, Course of Advanced Therapeutics;
${ }^{3}$ Department of Epidemiology and Preventive Medicine, Field of Human and Environmental Sciences,

Course of Health Research, Kagoshima University Graduate School of Medical and Dental Sciences,

Kagoshima 890-8520; ${ }^{4}$ Department of Urology, School of Medicine, Oita University, Oita 879-5593, Japan
\end{abstract}

Received November 28, 2005; Accepted January 17, 2006

\begin{abstract}
Thymidine phosphorylase (TP), also known as platelet-derived endothelial cell growth factor (PD-ECGF), has been implicated in bladder cancer angiogenesis and invasion. However, the molecular basis of its role in invasion remains unclear. We investigated the expression of TP and 10 invasionrelated genes in bladder cancers from 72 randomly selected patients by real-time two-step RT-PCR assay. We found that the expression levels of TP, MMP-9, uPA, and MMP-2 were significantly higher in invasive tumors than those in superficial tumors. Also, the expression level of TP significantly correlated with that of uPA, MMP-1, MMP-9, PAI-1 and VEGF. KK47/TP cells, bladder cancer cells that overexpress TP, had a higher expression of MMP-7 and MMP-9 than KK/CV cells that express lower level of TP in hypoxic condition. PC/TP cells, prostate cancer cells that overexpress TP, also had a higher expression of MMP-1 and MMP-7 than PC/CV cells that express no detectable TP. Taken together these data indicate that TP enhances the invasion of tumor cells through the induction of invasionrelated genes.
\end{abstract}

Correspondence to: Dr Misako Haraguchi, Department of Molecular Oncology, Field of Oncology, Course of Advanced Therapeutics, Kagoshima University, Graduate School of Medical and Dental Sciences, 8-35-1 Sakuragaoka, Kagoshima 890-8520, Japan

E-mail: haraguci@m3.kufm.kagoshima-u.ac.jp

Abbreviations: MMP, matrix metalloproteinase; TIMP-2, tissue inhibitor of metalloproteinase-2; uPA, urokinase plasminogen activator; PAI-1, plasminogen activator inhibitor-1; TP, thymidine phosphorylase

Key words: thymidine phosphorylase, invasion, bladder cancer, MMP-7, MMP-9, real-time PCR

\section{Introduction}

Cancer invasion is a complicated process involving the activity of multiple genes. As cancer cells undergo invasion, they must first attach to the target tissue's basal matrix and then degrade the basement membrane. Degradation of the extracellular matrix, or components of the basement membrane, is carried out mainly by proteases belonging to the matrix metalloproteinase family (MMPs) $(1,2)$. Elevated expression of the MMP-1 (3), MMP-2 (4), MMP-3 and MMP-9 (5) was correlated with the bladder cancer tumor stage, grade or prognosis. The membrane-type matrix metalloproteinase-1 (MT1-MMP), that induces specific activation of the precursor of the MMP-2 (6), is associated with bladder cancer progression. Urokinase-type plasminogen activator (uPA) (7) is an enzyme that degrades proteins in tissue basement membranes and the ECM. uPA and MT1-MMP have also been correlated with the stage and prognosis of patients with bladder cancer. High expression of MMP-2, -3, -7 and MT1-MMP are unfavorable prognostic features in breast cancer, gastric carcinoma and neuroblastoma (8-11). Vascular endothelial growth factor (VEGF) is an important mediator of tumor angiogenesis (12).

We have shown that TP, an enzyme that is involved in pyrimidine nucleoside metabolism, is identical to PD-ECGF (13). TP stimulates chemotaxis of endothelial cells in vitro, and displays angiogenic activity in vivo (14). Site-directed mutagenesis indicates that promotion of vessel growth by TP is dependent on the enzyme activity of TP (15). Among the degradation products generated from thymidine by TP activity, 2-deoxy-D-ribose (2DR), a dephosphorylated product derived from 2-deoxy-D-ribose-1-phosphate $(16,17)$, also displays chemotactic activity in vitro (14), and may function as a downstream mediator of TP. TP expression in stroma cells was associated with non-endometrioid-type carcinomas, high tumor grade, deep myometrial invasion, and advanced stage (18). In esophageal squamous cell carcinomas, statistically significant differences in serum TP level were observed depending on tumor size $(\mathrm{P}<0.01)$ and tumor depth $(\mathrm{P}<0.01)$ 
Table I. Primers designed for real-time quantitative PCR.

\begin{tabular}{lll}
\hline Gene & \multicolumn{2}{c}{ Forward primer } \\
\hline MMP-1 & 5'-GGACCTGGAGGAAATCTTGCT-3' & Reverse primer \\
MMP-2 & 5'-CCTGATGGCACCCATTTACAC-3' & 5'-GAGCTCCTGAATGCCCTTGA-3' \\
MMP-7 & 5'-AATGTTAAACTCCCGCGTCATAGA-3' & 5'-TGGAAATAGTGAGTATTCTGCAACATCT-3' \\
MMP-9 & 5'-CCCGGAGTGAGTTGAACCA-3' & 5'-CAGGACGGGAGCCCTAGTC-3' \\
MMP-14 & 5'-GATGGACACGGAGAATTTTGTG-3' & 5'-GGGAGGTAGACCAGGGTTGAG-3' \\
uPA & 5'-TCCGGAGCAGCTGAAAATG-3' & 5'-GGTGACTTCAGAGCCGTAGTTG-3' \\
TIMP-2 & 5'-ATCACCCTCTGTGACTTCATCG-3' & 5'-TGTGGTTCAGGCTCTTCTTCTG-3' \\
PAI-I & 5'-AGGCTGACTTCACGAGTCTTTCA-3' & 5'-CGTTCACCTCGATCTTCACTTTC-3' \\
DPD & 5'-GATTCTGGCTACCAGGCTATACAGTT-3' & 5'-GTACAGCCTGTACAAGTGTTCGGTTA-3' \\
TS & 5'-CGTGATGTGCGCAATCATG-3' & 5'-ACATCGCCAGCTACGCCCTGCTC-3' \\
TP & 5'-AATGACGAGGGCCTGGAGT-3' & 5'-TCTTACTGAGAATGGAGGCTGTGA-3' \\
VEGF & 5'-CCTGCGGACGGAATCCTAT-3' & 5'-TTGATCCGCATAATCTGCATG-3' \\
\hline
\end{tabular}

(19). There was also a significant correlation between the proportion of cells expressing TP in differentiated gastric adenocarcinomas and the depth of tumor invasion (20). These findings suggested that TP is involved in the invasiveness of differentiated gastric adenocarcinomas. TP was also significantly elevated in invasive bladder cancer (21-23) and, thus, may have a functional role in bladder cancer invasion. However, in spite of its potential importance for understanding cancer invasion the molecular basis for the involvement of TP in invasion remains unclear.

We examined whether TP modulates invasion by affecting the expression of invasion-related genes. We determined the expression of 10 invasion-related genes and 2 other genes in bladder cancers from 72 randomly selected patients with a real-time two-step RT-PCR assay. We found that TP expression strongly correlated with the expression of uPA, MMP-1, MMP-9, PAI-1 and VEGF. Furthermore, KK/TP bladder cancer cells that overexpress TP had a higher MMP-7 and MMP-9 expression than KK/CV cells in hypoxic condition that are commonly observed in tumor tissues. The data suggest that targeting TP expression might represent a novel anti-invasion approach.

\section{Materials and methods}

Patient characteristics. Between March 1996 and April 2000 we carried out transurethral resection (TUR) or total cystectomy in 72 patients with bladder cancer. Each tissue specimen was immediately snap frozen and stored at $-80^{\circ} \mathrm{C}$. We used these tissue specimen after approval of the local ethics committee. Pathological examination was performed by several pathologists, and pathological staging was diagnosed according to the Tumor-Nod-Metastasis (TNM) classification of stage. Tumor cells above the muscularis mucosa (MM) were labeled superficial, whereas those neoplastic cells located below the MM were considered invasive. There were 34 invasive- and 38 superficial-bladder cancer tissue samples.

RNA extraction. Total RNA from tissues and cells was isolated by Trizol (Life Technologies) according to the manufacturer's protocol. Isolated RNA was further purified with the RNeasy kit (Qiagen), according to the RNA clean-up protocol, and eluted in $50 \mu 1$ of RNase-free distilled water (Life Technologies). The quantity of RNA was measured spectrophotometrically.

cDNA synthesis. cDNA was synthesized from total RNA. Reverse-transcription was performed with a random primer using the ReverTra Ace- $\alpha$-kit, according to the manufacturer's protocol (Toyobo). cDNA $(1 \mu \mathrm{l})$ was employed in quantitative real-time PCR (an equivalent of $50 \mathrm{ng}$ total RNA).

Preparation of quantitation standards. Real-time quantitative RT-PCR primers targeting the VEGF, MMP-1, MMP-2, MMP-7, MMP-9, MMP-14, uPA, TIMP-2, PAI-1, TS, DPD, and TP genes were designed by using Primer Express software (Applied BioSystems, Japan, Ltd.) and the sequences are listed in Table I.

To construct RNA standards for these 12 genes, the genes were amplified with these primers using a cDNA template derived from the RNA of cells expressing a high level of these 12 genes. This procedure generated stable standards that could be stored for long-term use. The PCR products were cloned into the pMD-18 T Vector (Takara Biotechnology) in accordance with the manufacturer's instructions, and sequenced. The recombinant plasmid DNA was isolated and purified by the Qiaprep spin miniprep kit (Qiagen). The concentration of plasmid was measured by absorbance at $260 \mathrm{~nm}$ 


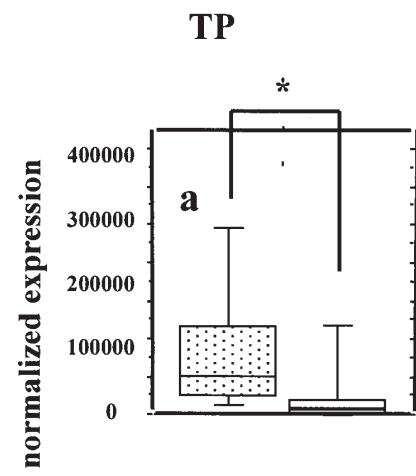

invasive superficial
MMP-2

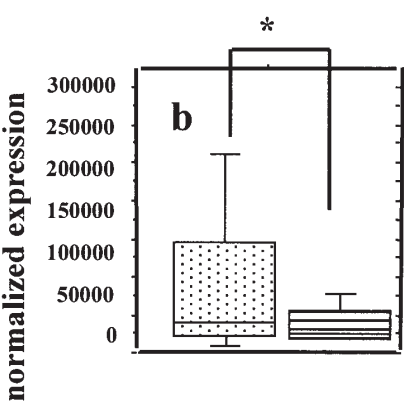

invasive superficial
MMP-9

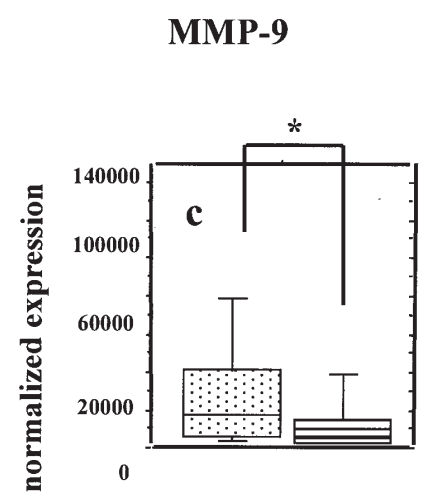

invasive superficial

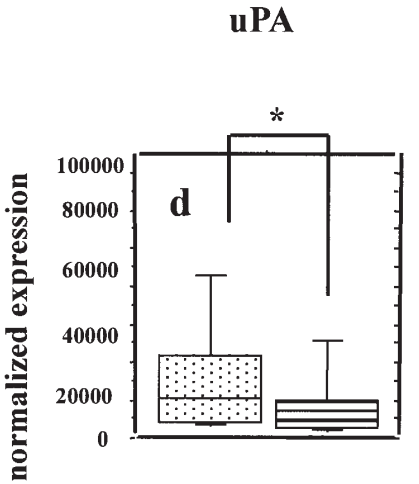

invasive superficial

Figure 1. Correlation of TP and invasion-related genes with bladder cancer. Relative mRNA levels of TP (a), MMP-2 (b), MMP-9 (c), and uPA (d) in invasive and superficial bladder cancer determined by quantitative real-time PCR. The y-axis represents copies of mRNA normalized to GAPDH. Each bar represents mean \pm SD. The number of invasive- and superficial-BT tissue samples is 34 and 38 respectively. ${ }^{*} \mathrm{P}<0.05$

and the copy number calculated from the molecular weight of the plasmid. Plasmids encoding MMP-2, MMP-9, MMP-14, and TIMP-2 were kindly provided by Dr Motoharu Seiki.

Quantitative real-time PCR. A novel quantitative PCR analysis was performed using an ABI PRISM-7900 HT sequence detector (Applied Biosystems Japan Ltd.). The probe was labeled with a reporter fluorescent dye, either FAM (6-carboxyfluorescein) or VIC, at the 5' end and a quencher fluorescent dye TAMRA (6-carboxy-tetramethyl-rhodamine) at the 3' end. The ABI PRISM-7900 HT sequence detector measured fluorescent emission that was synchronized with the thermal cycler during each extension step. Relative quantification of GAPDH and other mRNA was calculated by the comparative cycle threshold method. The Taqman human endogenous control plate (Applied Biosystems Japan Ltd.) was put into operation and GAPDH was used as a standard for the investigation. TaqMan ${ }^{\circledR}$ Universal PCR master mix $(10 \mu 1)$, $250 \mathrm{nmol} / \mathrm{l}$ probe and $900 \mathrm{nmol} / \mathrm{l}$ primer were used for each PCR run. Each reverse transcribed sample $(1 \mu 1)$ was added to $19 \mu \mathrm{l}$ of the PCR mixture. The thermal cycling conditions comprised an initial UNG incubation at $50^{\circ} \mathrm{C}$, followed by

AmpliTaq Gold activation at $95^{\circ} \mathrm{C}$ for $10 \mathrm{~min}$ and then 40 cycles of $95^{\circ} \mathrm{C}$ for $15 \mathrm{sec}$ and annealing and extension at $60^{\circ} \mathrm{C}$ for $1 \mathrm{~min}$. Experiments were performed with duplicates for each data point. Each PCR run consisted of a 5-point calibration curve, a no-template control, and the 72 bladder cancer specimen cDNAs. Each quantitation was performed with the standard curve method.

Cell lines and induction of hypoxia. The human prostate cancer cell line, PC-3, was purchased from the American Type Culture Collection. PC/TP cells, i.e. PC-3 cells transfected with TP/PD-ECGF cDNA, and PC/CV cells, a mock transfectant, were maintained in endotoxin-free RPMI-1640 medium supplemented with $10 \%$ fetal bovine serum (FBS). KK/TP cells, human bladder cancer KK47 cells transfected with TP/PD-ECGF cDNA, and KK/CV cells, a mock transfectant, were maintained in RPMI-1640 medium supplemented with $10 \%$ fetal bovine serum (FBS). KK/TP and KK/CV cells were seeded at $1 \times 10^{6}$ cells/well in 12-well plates, cultured under normoxic condition for 12-24 $\mathrm{h}$ and then under hypoxic condition for $16 \mathrm{~h}$. Hypoxia was induced with the Gas Pak pouch anaerobic system (Becton Dickinson and Company, Cockeysville, MD).

TP activities. Enzyme activity was assayed by the spectrophotometric method and radiometric assay. For spectrophotometric assay, cell lysates were incubated with a potassium phosphate buffer ( $\mathrm{pH} 6.5$ ) and $10 \mathrm{mM}$ thymidine at $37^{\circ} \mathrm{C}$ for $1 \mathrm{~h}$. The thymine formed was quantitated by the absorbance at $300 \mathrm{~nm}$. Enzyme-specific activity was expressed as the amount of thymine (nmol) formed/mg protein/h. For radiometric assay, enzymatic activities were determined by measuring the conversion of $\left[{ }^{14} \mathrm{C}\right]$-thymidine to $\left[{ }^{14} \mathrm{C}\right]$-thymine as described previously (25) with slight modification. KK/TP cells were seeded at $1 \times 10^{6}$ cells/ well in 12 -well plates and cultured with normoxic condition for $24 \mathrm{~h}$ and then under hypoxic condition for $24 \mathrm{~h} .\left[{ }^{14} \mathrm{C}\right]$-thymidine was then added in each culture medium and incubated at $37^{\circ} \mathrm{C}$ for $1 \mathrm{~h}$. Aliquots of media were spotted on PEIcellulose chromatography plates. Aliquots of $10 \mathrm{mM}$ thymidine and $1 \mathrm{mM}$ thymine were spotted as standards. The plates were developed in a solvent system of chloroformmethanl-acetic acid 17:3:1. The nucleoside and base were identified under UV light, scraped out and analyzed for radioactivity. The ratios of radioactivity of $\left[{ }^{14} \mathrm{C}\right]$-thymine to total radioactivity were determined.

Statistical analyses. Statistical analysis was performed using the StatView software package (Abacus, Berkeley, CA). Logistic regression model was used to determine independent predictors of bladder cancer invasion $(0$, superficial bladder cancer; 1 , invasive bladder cancer). All variables achieving statistical significance at $\mathrm{P}<0.05$ level in the univariate analysis were considered in the multivariate analyses. We also calculated the $95 \%$ confidence intervals of these odds ratios. Correlations between the log mRNA levels of TP gene expression and others were evaluated by the Spearman's rank test, with $\mathrm{P}<0.05$ being considered significant. A two-tailed Student's test was used with each individual experiment to determine the significance of any changes. 
Table II. Univariate and multivariate analysis of invasion-related factors using a logistic expression model in bladder cancer.

\begin{tabular}{|c|c|c|c|c|c|c|}
\hline \multirow{2}{*}{$\begin{array}{l}\text { Experimental } \\
\text { Variables }\end{array}$} & \multicolumn{3}{|c|}{ Univariate } & \multicolumn{3}{|c|}{ Multivariate } \\
\hline & $\beta$ & SE & $\mathrm{P}$-value & $\beta$ & $\mathrm{SE}$ & P-value \\
\hline $\mathrm{TP}$ & 0.881 & 0.227 & 0.0001 & 0.707 & 0.259 & 0.0064 \\
\hline MMP-9 & 0.717 & 0.214 & 0.0008 & 0.169 & 0.265 & 0.5240 \\
\hline uPA & 0.677 & 0.242 & 0.0052 & 0.156 & 0.255 & 0.5402 \\
\hline MMP-2 & 0.532 & 0.188 & 0.0046 & 0.430 & 0.247 & 0.0082 \\
\hline VEGF & 0.439 & 0.228 & 0.0543 & & & \\
\hline MMP-14 & 0.287 & 0.179 & 0.1088 & & & \\
\hline PAI-1 & 0.247 & 0.157 & 0.1144 & & & \\
\hline MMP-7 & 0.168 & 0.106 & 0.1141 & & & \\
\hline MMP-1 & 0.154 & 0.113 & 0.1733 & & & \\
\hline
\end{tabular}

Regression coefficients (Bs) and its standard errors (SEs) were obtained from logistic analysis using the presence of invasion as a dependent variable. Explanatory variables were included in logistic models after log transformation. Covariates of the multivariate regression model were TP, TIMP-2, MMP-9, uPA and MMP-2.

a

KK47 KK/CV1 KK/CV2 KK/TP1 KK/TP2

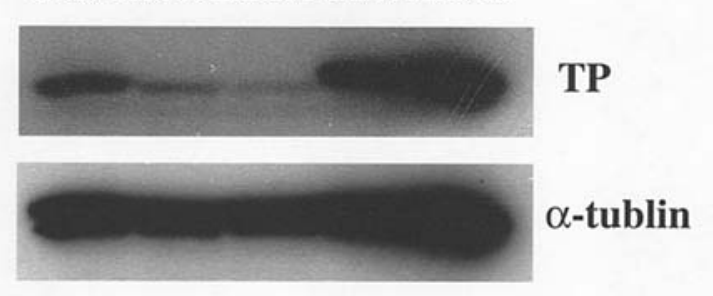

b

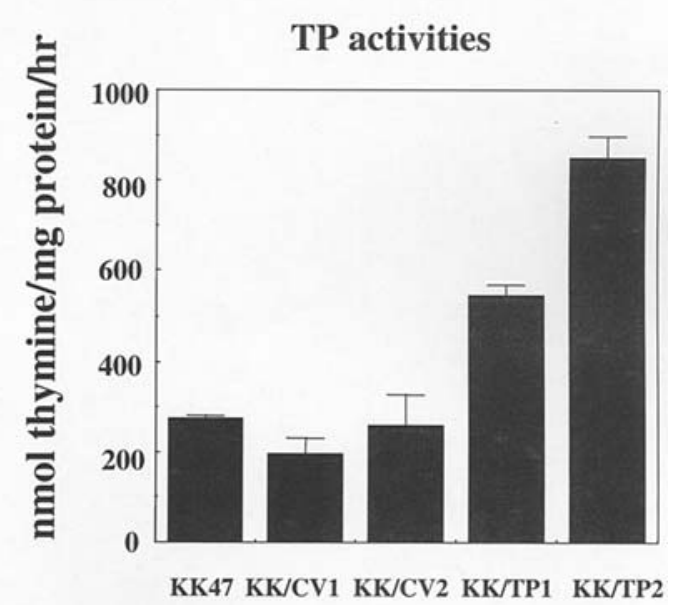

Figure 2. Generation of bladder cancer cells stably expressing TP. Immunoblot of TP protein in KK47 cells transfected with TP cDNA. Cytosolic fractions (100 $\mu \mathrm{g}$ of protein) were separated by SDS-9.4\% PAGE. TP levels were determined using an anti-TP monoclonal antibody and anti- $\alpha$-tublin monoclonal antibody (a). Enzyme activities of TP was assayed by the spectro-photometric method. TP activity is expressed as nmoles of thymidine catalyzed to thymine per min per mg of protein. Each column and bar represents the mean $\pm \mathrm{SD}(\mathrm{b})$.

\section{Results}

Correlation of TP and other genes with bladder cancer. The importance of TP and other genes for invasive bladder cancer was examined by comparing the expression of invasion-related gene/GAPDH ratios in superficial and invasive bladder cancers $(\mathrm{N}=72)$. The mean TP/GAPDH mRNA ratios was 59998 $(\mathrm{SE}=23394)$ for invasive bladder cancer and was 11939 ( $\mathrm{SE}=10824)$ for superficial cancer (Fig. 1a). The difference was highly significant in a two-tailed Student's test $(\mathrm{P}<0.001)$. The mRNA ratios to GAPDH of MMP-2 ( $\mathrm{P}=0.024)$, MMP-9
$(\mathrm{P}<0.001)$, and $\mathrm{uPA},(\mathrm{P}=0.0026)$ were significantly higher in invasive bladder cancers than those in superficial bladder cancers (Fig.1b-d). Univariate and multivariate logistic analyses were conducted to make comparisons between superficial and invasive bladder cancer with respect to the expression of variable genes including TP. Univariate analyses confirmed the findings described above: TP, MMP-9, MMP-2 and UPA mRNA ratios relative to GAPDH significantly increased in invasive bladder cancer (Table II). In the multivariate analysis, only the TP/GAPDH mRNA ratio was significantly elevated among the genes examined. 
Table III. Correlation between thymidine phosphorylase expression levels and expression of other invasion-related genes with the spearman rank test.

\begin{tabular}{lcc}
\hline Gene & $\mathrm{r}_{\mathrm{s}}$ & P-value \\
\hline uPA & 0.541 & $<0.0001$ \\
MMP-1 & 0.464 & $<0.0001$ \\
MMP-9 & 0.443 & 0.0002 \\
VEGF & 0.350 & 0.0032 \\
PAI-1 & 0.342 & 0.004 \\
MMP-7 & 0.341 & 0.041 \\
MMP-14 & 0.266 & 0.0247 \\
MMP-2 & 0.151 & 0.2039 \\
\hline
\end{tabular}
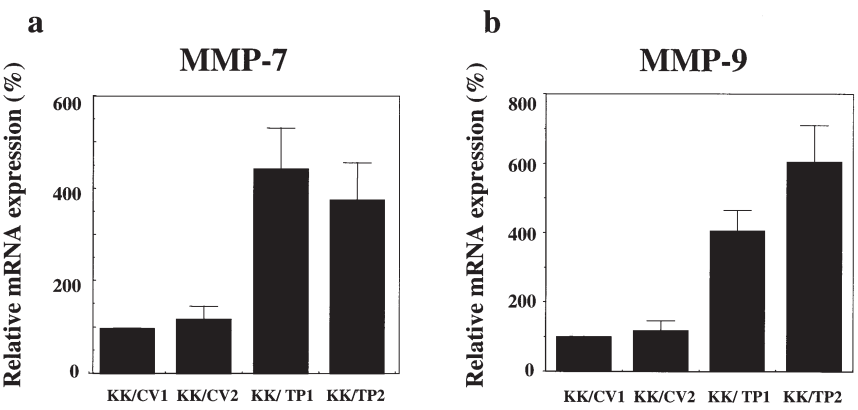

Figure 3. Overexpression of TP enhances the expression of invasion-related genes in hypoxic condition in bladder cancer cells. KK/TP and KK/CV cells were seeded at $1 \times 10^{6}$ cells/well in 12 -well plates and cultured under normoxic condition for 12-24 h and then under hypoxic condition for $16 \mathrm{~h}$. Hypoxia was induced with the Gas Pak pouch anaerobic system. Relative mRNA levels of MMP-7 (a), MMP-9 (b) in KK/CV and KK/TP cells were determined by quantitative real-time PCR. Each column and bar represents the mean \pm SD.

Correlation between the expression levels of TP and other genes in bladder cancer. To determine if any correlation existed between the expression level of TP and other genes in bladder cancer, we measured the mRNA levels of TP and other genes and evaluated them by the Spearman's rank test. The expression of TP was significantly correlated with that of UPA, MMP-1, MMP-9, MMP-7, PAI-1, DPD and VEGF (Table III). In contrast, there was no correlation between TS expression and TP expression (data not shown).

Overexpression of TP enhances the expression of invasionrelated genes in bladder cancer KK47 cells. A correlation between TP and invasive gene expression suggested the possibility that TP expression might modulate the expression of invasion-related genes. To test this possibility we generated the TP-overexpressing bladder cancer (KK/TP) cells. Parental KK47 is a superficial transitional cell carcinoma (TCC) cell line and had endogenous TP expression and enzymatic activity. KK/TP1 and KK/TP2 cells had higher TP
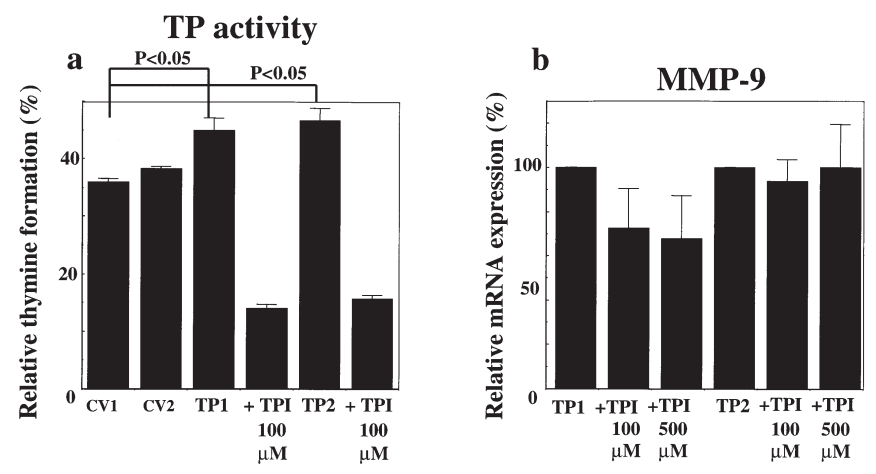

Figure 4. The enhanced expression of MMP-9 mRNA caused by TP overexpression was not suppressed by treatment of TPI. KK/CV and KK/TP cells were seeded at $1 \times 10^{6}$ cells/well in 12-well plates and cultured without or with 100 and $500 \mu \mathrm{M}$ of TPI under normoxic condition for $24 \mathrm{~h}$ and then under hypoxic condition for $24 \mathrm{~h}$. Enzymatic activities were determined by adding $\left[{ }^{14} \mathrm{C}\right]$-thymidine in the culture media and measuring the conversion to $\left[{ }^{14} \mathrm{C}\right]$-thymine (a), Relative mRNA levels of MMP-9 in KK/TP cells were determined by quantitative real-time PCR (b). Each column and bar represents the mean $\pm \mathrm{SD}$.

expression and enzymatic activity than mock transfected KK/CV1 and KK/CV2 cells (Fig. 2a and b).

We measured the expression level of invasive genes in $\mathrm{KK} / \mathrm{TP}$ cells and compare them to those in KK/CV cells in various conditions using real-time quantitative PCR. The KK/TP cells had a higher expression of MMP-7 (Fig. 3a) and MMP-9 (Fig. 3b) than the KK/CV cells in hypoxic condition. In normoxic condition, the expression of MMP-9 in $\mathrm{KK} / \mathrm{CV}$ and KK/TP cells were not correlated with the level of TP expression (data not shown). In contrast to MMP-7 and MMP-9, the expression of MMP-2 in these cells were not correlated with TP expression either in normoxic or hypoxic condition (data not shown).

The enhanced expression of invasion-related genes caused by TP overexpression was not suppressed by treatment of TPI. We next examined whether the enzymatic activity of TP is required for its function. We determined if inhibition of the TP activity with TPI, a specific TP inhibitor $\left(\mathrm{Ki}=2 \times 10^{-8} \mathrm{M}\right)$, could abrogate its effect. We assayed the level of TP enzymatic activity of KK/TP cells using a radiometric assay. Pretreatment with $100 \mu \mathrm{M}$ of TPI for $24 \mathrm{~h}$ in normoxic condition and $24 \mathrm{~h}$ in hypoxic condition greatly reduced the TP enzymatic activity in the KK/TP cells to a much lower level compared to the mock-transfected KK/CV cells. Pretreatment with 100 and $500 \mu \mathrm{M}$ of TPI for $24 \mathrm{~h}$ in normoxic condition and $24 \mathrm{~h}$ in hypoxic condition did not significantly alter the expression of MMP-9 in KK/TP2 cells (Fig. 4). Although TPI seemed to partially suppress MMP-9 expression in KK/TP1 cells, the expression level was higher than that of KK/CV cells. TPI was not cyto-toxic to the cells as it did not have any effect on the number of apoptotic cells at this concentration (data not shown).

Overexpression of TP enhances the expression of invasionrelated genes in prostate cancer PC-3 cells. Prostate cancer is adenocarcinoma with hormone dependency. Cellular properties of these cells appear to be different from bladder cancer 
a

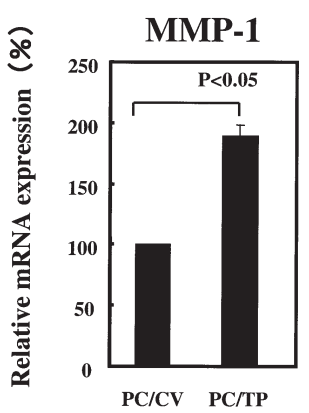

b

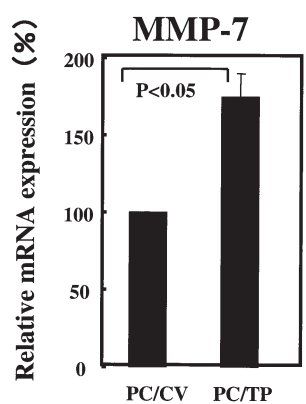

Figure 5. Enhanced expression of invasion-related genes by TP overexpression in prostate cancer cells. Relative mRNA levels of MMP-1 (a), MMP-7 (b) in PC/CV and PC/TP cells were determined by quantitative realtime PCR. Each column and bar represents the mean \pm SD.

cells. Thus, we examined if overexpression of TP enhances the expression of MMPs in prostate cancer PC-3 cells. Expression levels of MMP-1 and MMP-7 in PC/TP cells were higher than those in $\mathrm{PC} / \mathrm{CV}$ cells in normoxic condition (Fig. 5a and b). This suggest a role for TP in the regulation of invasive gene expression in various cell types.

\section{Discussion}

Recent studies suggest that bladder cancer invasion is regulated by several factors. These factors induce more aggressive tumors and a more unfavorable prognosis. The ubiquitous expression of many invasion-related genes in bladder cancer (i.e., VEGF, MMP-2, MMP-9, uPA, and TP) suggests that bladder cancer invasion is a multi-step process. However, the contribution of individual genes to invasion appears to vary between different cancers. To our knowledge, this is the first time that co-expression of 10 invasion-related genes in 72 human bladder cancers was quantified. The findings presented in Table II suggest that TP, MMP-9, uPA and MMP-2 are involved in the invasiveness of bladder cancer. Surprisingly, among these genes, TP had the highest coefficient. This suggest that TP is a strong risk factor for invasiveness in bladder cancer. Furthermore, TP expression was significantly correlated with the expression of invasion-related genes such as UPA, MMP-1, MMP-9, or VEGF in bladder cancer.

Our data further suggested that one mechanism by which TP modulates invasiveness is by enhancement of expression of invasive genes such as MMP-7 and MMP-9 in bladder cancer cells in hypoxic condition. Since many tumors contain a hypoxic micro-environment, the expression of TP may play important roles in the progression and invasion of bladder cancer. The mechanism of TP induction of MMP expression is still unclear. Because the treatment with TP inhibitor TPI did not suppress the enhancement of expression of MMP-9 in KK/ TP2 cells, TP has other biological roles independent of its enzymatic activity. TP-transfectants showed augmented activity of Akt compared to the respective mock-transfectants (data not shown). PI-3K and Akt are mediators of Activator Protein-1 (AP-1) induction (25). The AP-1 sites are upstream of the transcriptional start sites of MMP-7, MMP-9 and MMP-1 and has long been thought to play a dominant role in the transcriptional activation of the MMP promoters (26). The
AP-1 sites are also upstream of transcriptional start sites of uPA and VEGF. On the other hand, the promoter of MMP-2 lacks the adjacent AP-1 elements (26). AP-1 induced by activated Akt might enhance the transcription of the invasionrelated genes. Alternatively, Akt/PKB activates NF-кB, a family of transcription factors that increase transcription of a wide range of genes. MMP-9 has an NF- $\mathrm{KB}$ binding site in its promoter region and is therefore expressed in an NF-кBdependent manner (27). Thus, TP might induce MMP expression via Akt activation. We observed enhanced expression of MMPs in PC/TP cells even in normoxic condition. Under hypoxic condition, 'hypoxia-response' signaling system is activated. Ultimately, this signaling system upregulates the expression of a network of gene products such as VEGF and HIF- $1 \alpha$ that increase the propensity of the cell to survive even in this adverse environment (28). TP might need to act in harmony with such proteins to enhance expression of MMPs in KK/TP cells. Although, the exact role of TP in invasion remains unclear, TP seems to enhance the expression of MMPs in each tumor. The compounds that could suppress TP expression might become promising anti-tumor drugs.

In summary, we have provided quantitative data to support the role of TP in invasive activity of bladder cancer cells. We have demonstrated that the expression level of TP is correlated with those of several invasive genes, and TP induced the expression of MMP-7 and MMP-9 in human bladder carcinoma KK47 cells. These studies promote the understanding of molecular mechanisms underlying bladder cell invasion and may allow the future development of antiinvasive drugs based on inhibition of TP-signaling pathways.

\section{References}

1. Friedl P and Wolf K: Tumour-cell invasion and migration: diversity and escape mechanisms. Nat Rev Cancer 3: 362-374, 2003

2. Hood JD and Cheresh DA: Roles of Integlins in cell invasion and migration. Nat Rev Cancer 2: 91-100, 2002.

3. Hara I, Miyake H, Hara S, Arakawa S and Kamidono S: Significance of matrix metalloproteinases and tissue inhibitors of metalloproteinase expression in the recurrence of superficial transitional cell carcinoma of the bladder. J Urol 165: 1769-1772, 2001.

4. Papathoma AS, Petraki C, Grigorakis A, Papakonstantinou H, Karavana V, Stefanakis S, Sotsiou F and Pintzas A: Prognostic significance of matrix metalloproteinases 2 and 9 in bladder cancer. Anticancer Res 20: 2009-2013, 2000.

5. Nakopoulou L, Gakiopoulou H, Zervas A, Giannopoulou I, Constantinides C, Lazaris AC, Liapis H, Kyriakou G and Dimopoulos C: MMP-3 mRNA and MMP-3 and MMP-1 proteins in bladder cancer: a comparison with clinicopathologic features and survival. Appl Immunohistochem Mol Morphol 9: 130-137, 2001.

6. Kinoshita T, Sato H, Okada A, Ohuchi E, Imai K, Okada Y and Seiki M: TIMP-2 promotes activation of progelatinase A by membrane-type 1 matrix metalloproteinase immobilized on agarose beads. J Biol Chem 273: 16098-16103, 1998.

7. Seddighzadeh M, Steineck G, Larsson P, Wijkstrom H, Norming U, Onelov E and Linder S: Expression of uPA and uPAR is associated with the clinical course of urinary bladder neoplasms. Int J Cancer 99: 721-726, 2002.

8. Ghilardi G, Biondi ML, Caputo M, Leviti S, De Monti M, Guagnellini E and Scorza R: A single nucleotide polymorphism in the matrix metalloproteinase- 3 promoter enhances breast cancer susceptibility. Clin Cancer Res 8: 3820-3823, 2002.

9. Liu XP, Kawauchi S, Oga A, Tsushimi K, Tsushimi M, Furuya T and Sasaki K: Prognostic significance of matrix metalloproteinase-7 (MMP-7) expression at the invasive front in gastric carcinoma. Jpn J Cancer Res 93: 291-295, 2002. 
10. Talvensaari-Mattila A, Paakko P, Blanco-Sequeiros G and Turpeenniemi-Hujanen T: Matrix metalloproteinase-2 (MMP-2) is associated with the risk for a relapse in postmenopausal patients with node-positive breast carcinoma treated with antiestrogen adjuvant therapy. Breast Cancer Res Treat 65: 55-61, 2001.

11. Sakakibara M, Koizumi S, Saikawa Y, Wada H, Ichihara T, Sato H, Horita S, Mugishima H, Kaneko Y and Koike K: Membrane-type matrix metalloproteinase-1 expression and activation of gelatinase A as prognostic markers in advanced pediatric neuroblastoma. Cancer 85: 231-239, 1999.

12. Millauer B, Shawver LK, Plate KH, Risau W and Ullrich A: Glioblastoma growth inhibited in vivo by a dominant-negative Flk-1 mutant. Nature 367: 576-579, 1994.

13. Furukawa T, Yoshimura A, Sumizawa T, Haraguchi M, Akiyama S, Fukui K, Ishizawa M and Yamada Y: Angiogenic factor. Nature 356: 668, 1992

14. Haraguchi M, Miyadera K, Uemura K, Sumizawa T, Furukawa T, Yamada K, Akiyama S and Yamada Y: Angiogenic activity of enzymes. Nature 368: 198, 1994.

15. Miyadera K, Dohmae N, Takio K, Sumizawa T, Haraguchi M, Furukawa T, Yamada Y and Akiyama S: Structural characterization of thymidine phosphorylase purified from human placenta. Biochem Biophys Res Commun 212: 1040-1045, 1995.

16. Iltzsch MH, El-Kouni MH and Cha S: Kinetic studies of thymidine phosphorylase from mouse liver. Biochemistry 24: 6799-6807, 1985

17. Krenitsky TA, Koszalka GW and Tuttle JV: Purine nucleoside synthesis, an efficient method employing nucleoside phosphorylases. Biochemistry 20: 3615-3621, 1981.

18. Sivridis E, Giatromanolaki A, Anastasiadis P, Georgiou L, Gatter KC, Harris AL, Bicknell R and Koukourakis MI: Angiogenic co-operation of VEGF and stromal cell TP in endometrial carcinomas. J Pathol 196: 416-422, 2002.

19. Shimada H, Takeda A, Shiratori T, Nabeya Y, Okazumi S, Matsubara H, Funami Y, Hayashi H, Gunji Y, Kobayashi S, Suzuki T and Ochiai T: Prognostic significance of serum thymidine phosphorylase concentration in esophageal squamous cell carcinoma. Cancer 94: 1947-1954, 2002.
20. Shimaoka S, Matsushita S, Nitanda T, Matsuda A, Nioh T, Suenaga T, Nishimata Y, Akiba S, Akiyama S and Nishimata H: The role of thymidine phosphorylase expression in the invasiveness of gastric carcinoma. Cancer 88: 2220-2227, 2000.

21. Sawase K, Nomata K, Kanetake H and Saito Y: The expression of platelet-derived endothelial cell growth factor in human bladder cancer. Cancer Lett 14: 35-41, 1998.

22. Droller MJ: Prognostic significance of platelet-derived endothelial cell growth factor/thymidine phosphorylase expression in stage pT1 G3 bladder cancer. J Urol 168: 854, 2002.

23. Jones A, Fujiyama C, Turner K, Cranston D, Williams K, Stratford I, Bicknell R and Harris AL: Role of thymidine phosphorylase in an in vitro model of human bladder cancer invasion. J Urol 167: 1482-1486, 2002.

24. Eng-Gan T, Hallman L, Pilikington GR and van der Weyden MB A rapid and simple radiometric assay for thymidine phosphorylase of human peripheral blood cells. Clin Chim Acta 116: 211-236, 1981.

25. Li J, Chen H, Tang MS, Shi X, Amin S, Desai D, Costa M and Huang C: PI-3K and Akt are mediators of AP-1 induction by 5-MCDE in mouse epidermal Cl41 cells. J Cell Biol 165: 77-86, 2004.

26. Benbow U and Brinckerhoff CE: The AP-1 site and MMP gene regulation: what is all the fuss about? Matrix Biol 15: 519-526, 1997.

27. Kim D, Kim S, Koh H, Yoon SO, Chung AS, Cho KS and Chung J: Akt/PKB promotes cancer cell invasion via increased motility and metalloproteinase production. FASEB J 15: 1953-1962, 2001.

28. Jones A, Fujiyama C, Blanche C, Moore JW, Fuggle S, Cranston D, Bicknell R and Harris AL: Relation of vascular endothelial growth factor production to expression and regulation of hypoxia-inducible factor- 1 alpha and hypoxiainducible factor-2 alpha in human bladder tumors and cell lines. Clin Cancer Res 7: 1263-1272, 2001. 